\title{
Study of Citronella Mosquito Repellent Plants in Tubman University, Harper, Maryland County, Liberia (Paper I)
}

\author{
Thomas - Connor I * Adetunde, I. ${ }^{1,2}$ \\ ${ }^{1}$ WVS Tubman University, Harper, Maryland County, Liberia \\ ${ }^{1}, *$ College of Health Sciences, Department of Nursing \\ ${ }^{2}$ College of Engineering and Technology
}

\begin{abstract}
Mosquito repellant plants should be of paramount importance in the present day in Africa where there is rising number of mosquito borne illnesses. Alarming increase in the range of mosquitoes in Africa is as a result of deforestation, stagnant waters, artificial containers, non-recyclableradial tires, trees holes, water drainage systems, ditches, ponds, lakes, lagoons, marshes, swamps, floodwater sites, dirty environments, industrialized farming/irrigated fields. This paper focuses on the Citronella Mosquito repellent plants, with a special reference to Tubman University environments. The present Citronella mosquito repellant plants were preferred over chemical mosquito repellents. It was observed that Citronella plants serve as retardant of mosquitos' growth where they were planted and also prevent the incidence of malaria among the residents. Mortality of Mosquitos was found to increase proportionately with increase in planted Citronella plants.
\end{abstract}

Keywords: Citronella Plants, Tubman University, Mosquito Borne Illnesses, Mosquito Repellents, Mosquitoes in Africa, Malaria.

\section{INTRODUCTION}

Right from the ages immemorial our fore fathers during the ancient time have been using plants as their prospective source of medicine; though in a crude form, to the present age it may look unhygienic but it works for them to cure various ailments. The conventional herbal medical system has been practiced internationally from ancient times; as a result, a great volume of literature is available on the antimicrobial activity of a variety of plant species. It is supposed that drugs developed from plant sources may have minimum and very slow to induce drug resistance among the pathogens. From this perception, it is essential to screen a variety of plants with potential antimicrobial activity for periodical introduction to control the drug resistance among the human pathogens. Bansode and Chavan (2015), [5].The importance of plants led to research into citronella mosquito repellent plants.

Citronella plant is commonly found under a number of names, such as citronella plant, mosquito plantGeranium, citrosa Geranium and Pelargonium Citrosum. Though many of its names leave the impression that it contains citronella, which is a common ingredient in insect repellent, the plant is actually a variety of scented geranium that simply produces a citronella-like scent when the leaves are crushed. Citronella is a beautiful perennial clumping grass that emits a strong aroma. That aroma masks other scents, and keeps mosquitoes from being attracted to things located around it. The citronella plant has a much stronger aroma than other mosquito repellents that contain citronella, it is naturally mosquito repellents. A true citronella plant closely resembles lemongrass [3], while this imposter is larger with foliage that resembles parsley [4] leaves. It also produces lavender blooms in the summer [2]. AakankshaWany, etal.2013, said that Citronella grass is mainly grown for its commercial essential oils and the systematic study of its chemical composition resulted in several other benefits apart from the development of analytical methods for quality assessment. This quality assessment of the oil gives a basic insight into the chemical composition and the extent to which the main constituents varies in proportion.

Chistophers 1947 and Dethier 1947, emphasized in his article titled Mosquito repellents, Being a report of the work of the mosquito repellent inquiry, Cambridge and in his book title Chemical insect attractants and repellents respectively, that citronella plant is one of the earliest well known mosquito 
repellents (being used as early as 1882). Citronella plant is a tall, hardy grass that can grow well anywhere as long as there isn't frost. Citronella is a perennial 'clumping' grass which grows to a height of five to six feet. It can be grown directly in the ground in any climate where frost does not occur and it flourishes when receiving direct sunlight. In northern climate zones, people often grow citronella in large pots that they bring indoors for winter.

There are several mosquito plants/leaves (fresh or smoke of the leave oil) that people used to, notably among them are Piper betel Linn, DEET, O. suave and O. kilmandscharium (Lamiaceae), Azadirachtaindica (Meliaceae) Eucalyptus globules (Myrtaceae), Lantana camara (Verbenaceae), Lemon grass (Cymbopogoncitratus), Marigolds, Geranium plant, Garlic plants, Basil, Rosemary, Catnip, Lavender, Yarrow tea, Tansies, just to mention but a few.The flowers/oil extracted from these grasses/leaves/plants are also used to rub the skin or place on pulse points.

According to Patel et al; in their paper titled "A review on: Mosquito repellant methods", ..." control of mosquitoes is something of utmost importance in the present day with rising number of mosquito borne illnesses. Mosquitoes need to be exterminated using the right tools and with a little bit of effort. The main reason for this is as a result of the ubiquitous menace problems mosquito caused through the world. African populations are extremely affected by Malaria, which is been caused by blood parasites transmitted from person to person through the bites of infected mosquitoes. Malaria often causes death, according to the latest estimates, released in December 2014, there were about 198 million cases of malaria in 2013 (with an uncertainty range of 124 million to 283 million) and an estimated 584000 deaths (with an uncertainty range of 367000 to 755000 ). Even though, malaria mortality rates have fallen by $47 \%$ globally since 2000 , and by $54 \%$ in the WHO African Region; but the most vulnerable people are persons with no or little immunity against the disease. In areas with high transmission (such as Africa South of the Sahara), the most vulnerable groups are, the young children, who have not yet developed partial immunity to malaria, pregnant women, whose immunity is decreased by pregnancy, especially during the first and second pregnancies and the travelers or migrants coming from areas with little or no malaria transmission, who lack immunity.

As reported by Eliningaya et al [7] in their article "Ethnobotanical study of some of mosquito repellent plants in north-eastern Tanzania" in the Malaria Journal of BioMed Central that the burden of malaria has been increasing due to development of resistance against both anti - malaria drugs and insecticides, complex social structures, and rapid environmental changes that have intensified in the last decade [7,8]. Consequently, there is no single method of malaria control that is completely effective in high transmission areas [9 -11]. Even the most widely tested interventions, using bed nets treated with pyrethroid insecticides have proven difficult to implement correctly because of problems related to equity, accessibility, user compliance and insecticide resistance [12,13]. All the above necessitated the idea of going back to the ancient time when our fore father practiced the use of mosquito repellant plants. This warrants the research by trying to seeing the efficacy, the significant account and important activity of Citronella Plants at Chinese building and the Tubman Hall of WVS Tubman University.

The authors of this concept paperbelieve that along withother know preventive measures using the natural environment such as the growing of citronella mosquito repellent plants and scrubs around densely populate work, play and residential areas maybe one way of economically and effectively reducing the growth of disease carrying mosquitos. This sparked the desire to conduct a research that would look at the efficacy, the significance and important activity of Citronella plants at faculty and staff residents. The focus is on specific areas known as the "Dean's and Chinese*residential buildings of William VS Tubman University located in Harper, Maryland County Republic of Liberia. (*Named after the company who constructed the first sixteen, one-bedroom faculty complexes).

\section{MATerials AND MethodS}

\section{Study Area:}

The test survey for the concentration of mosquitos was carried out in residence areas of the Chinese building and the Tubman hall of W. V .S. Tubman University, Harper, Maryland County of Republic of Liberia.The William V. S. Tubman University is a "new - old" institution of higher learning. It is 
"old" in that it is an institution of higher learning formerly known as "William V. S. Tubman College of Technology", TC for short. TC began in 1978 as a gift from the people of Maryland Countyto their beloved son of Maryland, Liberia's $19^{\text {th }}$ President, William V. S. Tubman. TC began in August 1978, with an enrollment of 87 students. TC thrived in producing $50 \%-60 \%$ of Liberia's technocrats in the fields of architectural, civil, electrical, electronic, and mechanical engineering.(Tubman University Handbook, 2003).

\section{The overview of the Planted Citronella Plants at Chinese building and the Tubman Hall}

The overview of the planted Citronella Plants at Chinese building and the Tubman hallare shown in Figures 1 to 9. Figure 1 to 5 show the planted Citronella Plants at Tubman Hall and Figures 6 to 9 show the planted Citronella Plants at Chinese building. These plants were to carry out study to evaluate repellency of mosquito in the university. The attempt of doing so is to see how a natural based mosquito repellant "Citronella" is more effective, cheaper, environmental friendly and non hazardous to the environment. Evidence has shown that plant products have been used in many parts of the world for killing or plant (Seyoum A et al). Various plants were used for agricultural and domestic pest control in China and other countries reported by Secoy and Smith (1983) and Yang and Tang (1988). Kulkarni and Kumbhojkar 1996, 2003) also reported that, the local and tribal people are used to various plants like Kanapa for the pest control. In an article written by Eliningaya J. Kweka et al (2008) that account of plants used as insect repellents in the north - eastern Tanzania and evaluates the feeding inhibition, knockdown effect and mortality effect of two common repellents, Octimum suave and Ocmum Kilimandscharicum plants against An. gambiaess, An. Arabiensis and Cx.quinquefasciatus.

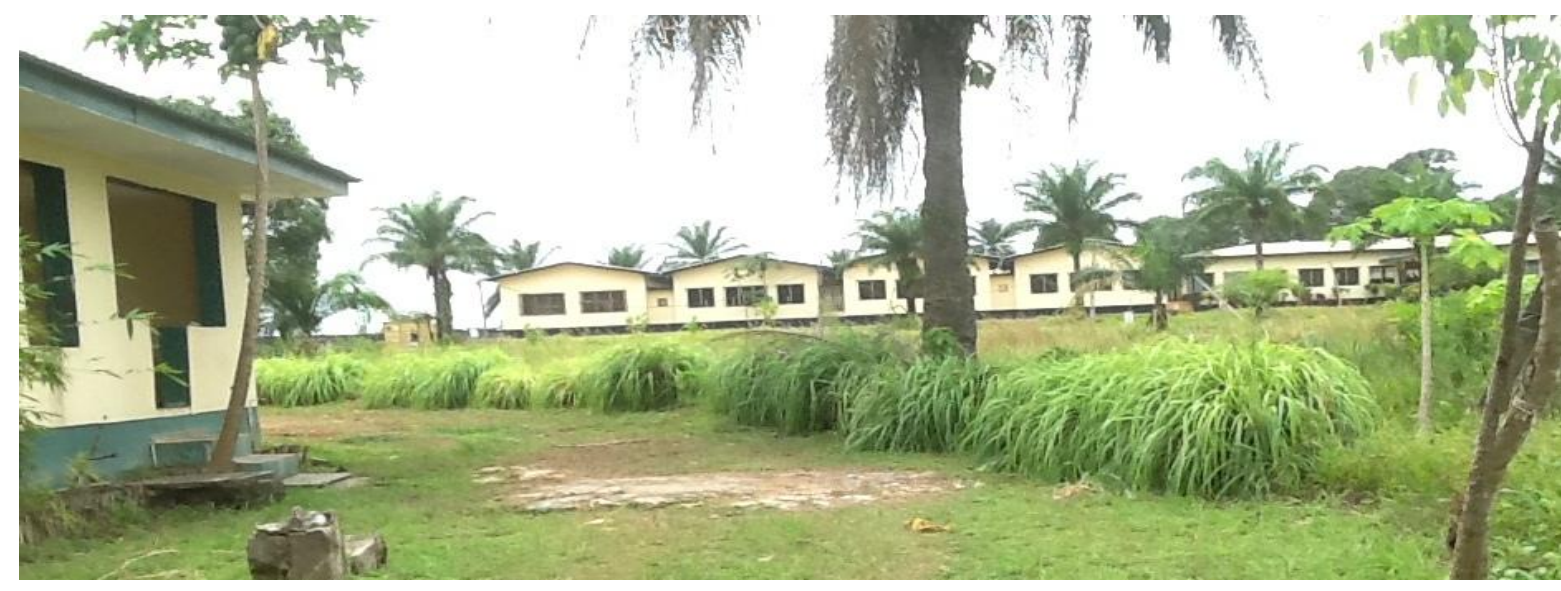

Figure 1. Tubman Hall Resident for the Academic Staff at Tubman University showing the Citronella Plants

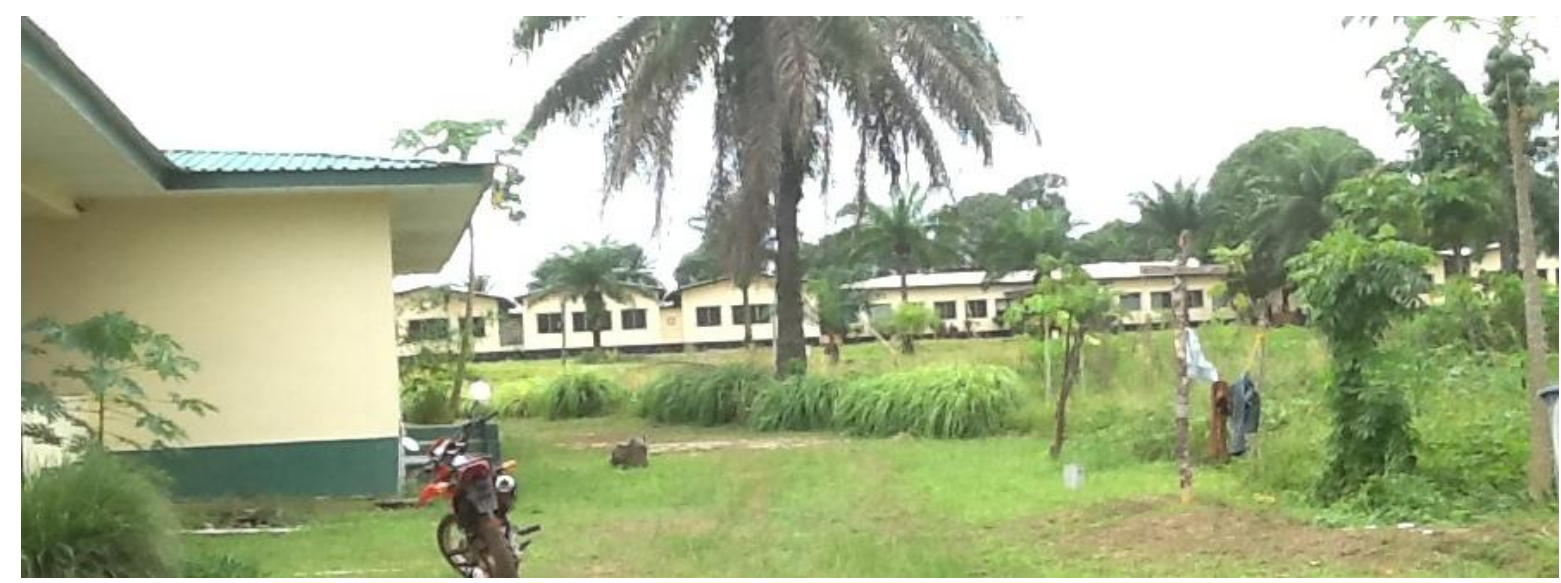

Figure 2. Left side view of the Deans' Resident at Tubman Hall in Tubman University showing the Citronella Plants 


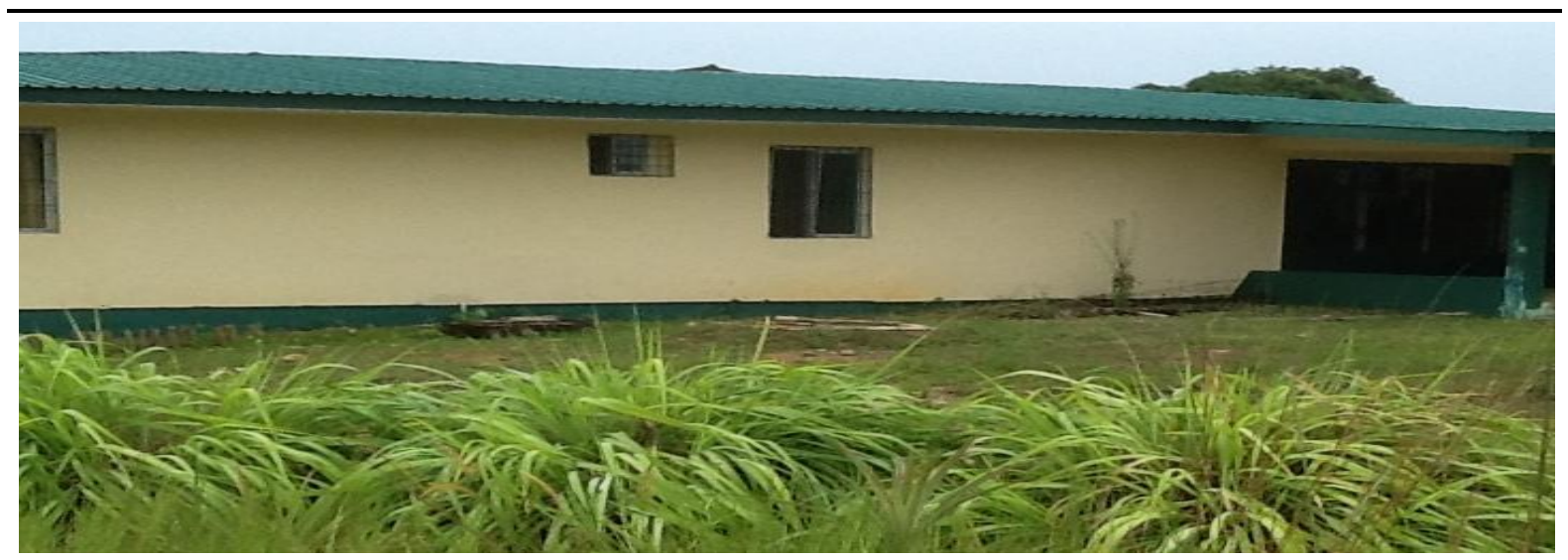

Figure 3. Right side view of the Deans' Resident at Tubman Hall in Tubman University showing the Citronella Plants

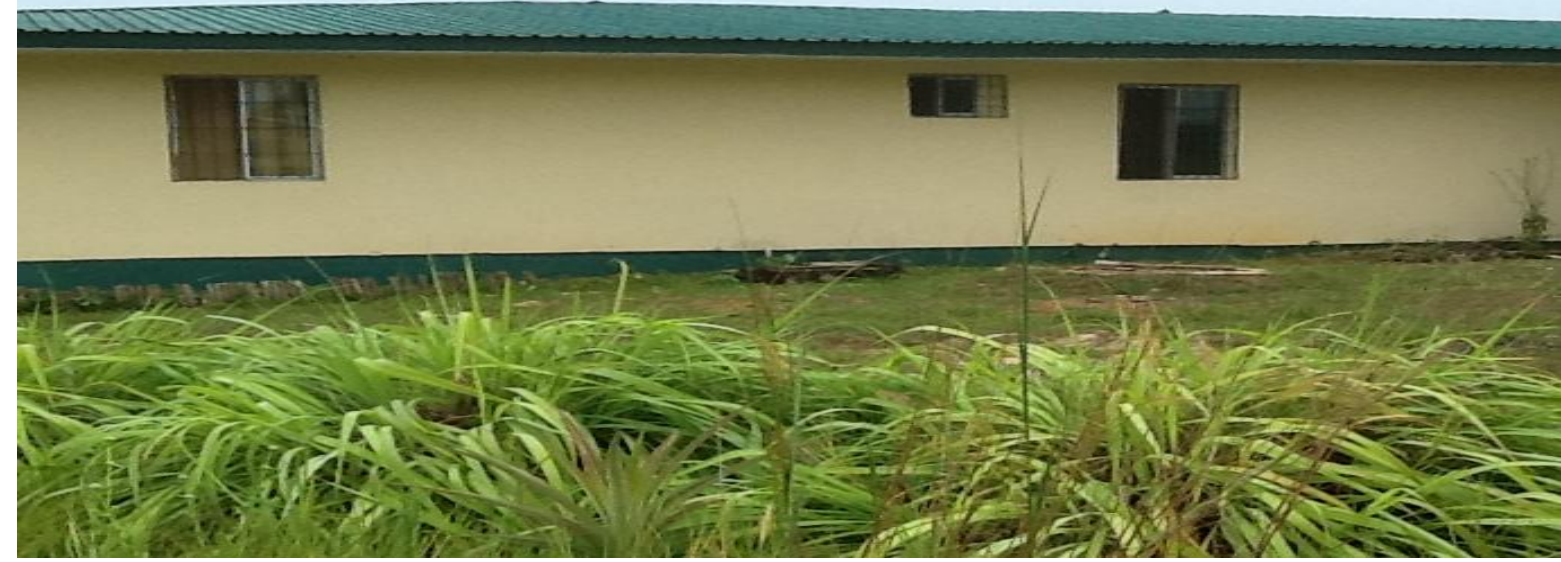

Figure 4. Part of the Left side view of Deans's Resident at Tubma's Hall in Tubman University showing the Citronella Plants

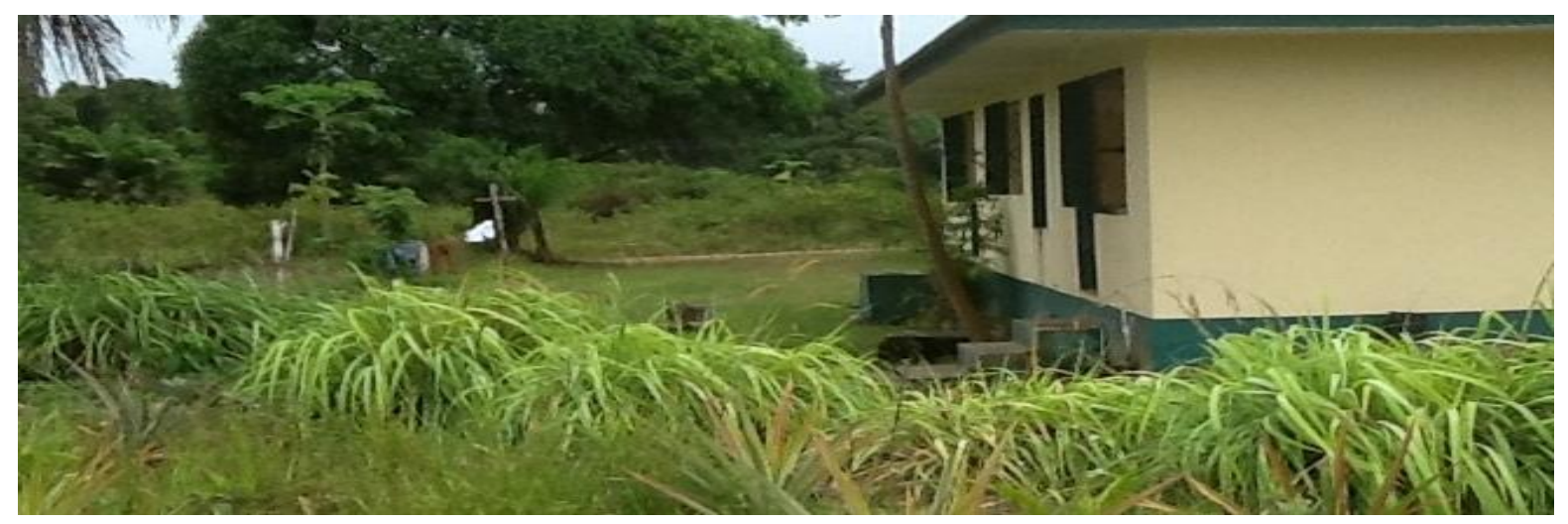

Figure 5. Back View of Deans' residence at Tubman Hall in Tubman University showing the Citronella Plants

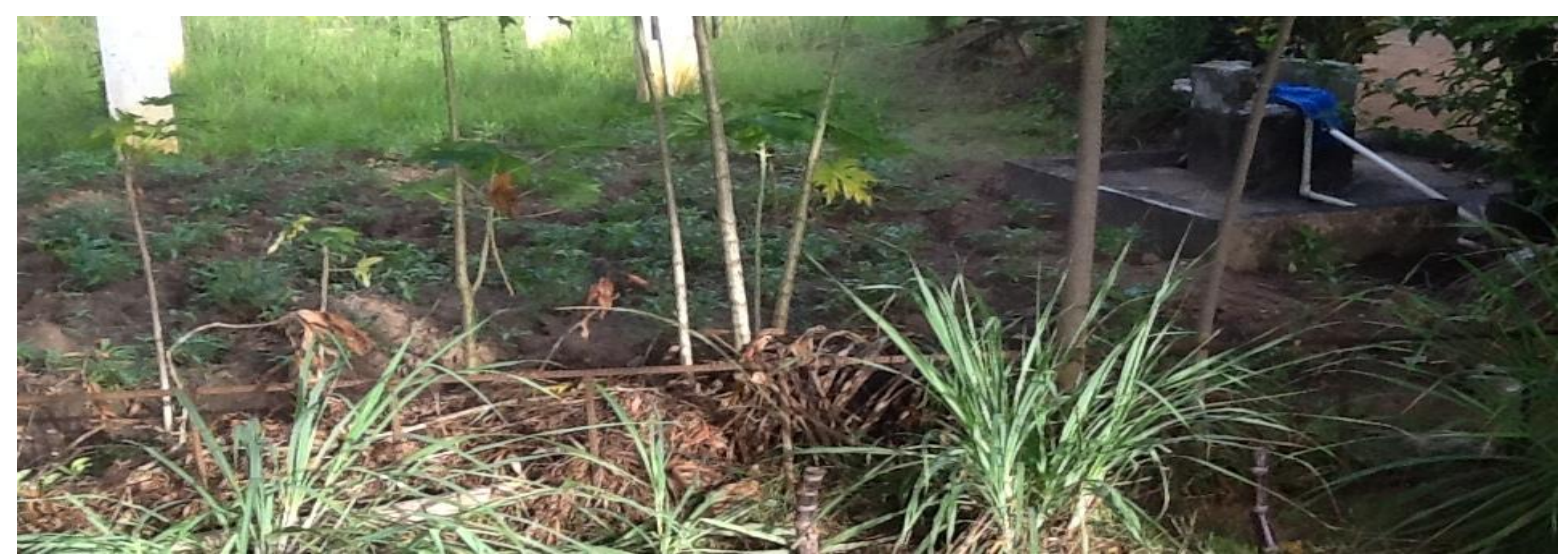

Figure 6. Left end side of theTubman's Hall showing the Citronella Plants 
Study of Citronella Mosquito Repellent Plants in Tubman University, Harper, Maryland County, Liberia (Paper I)

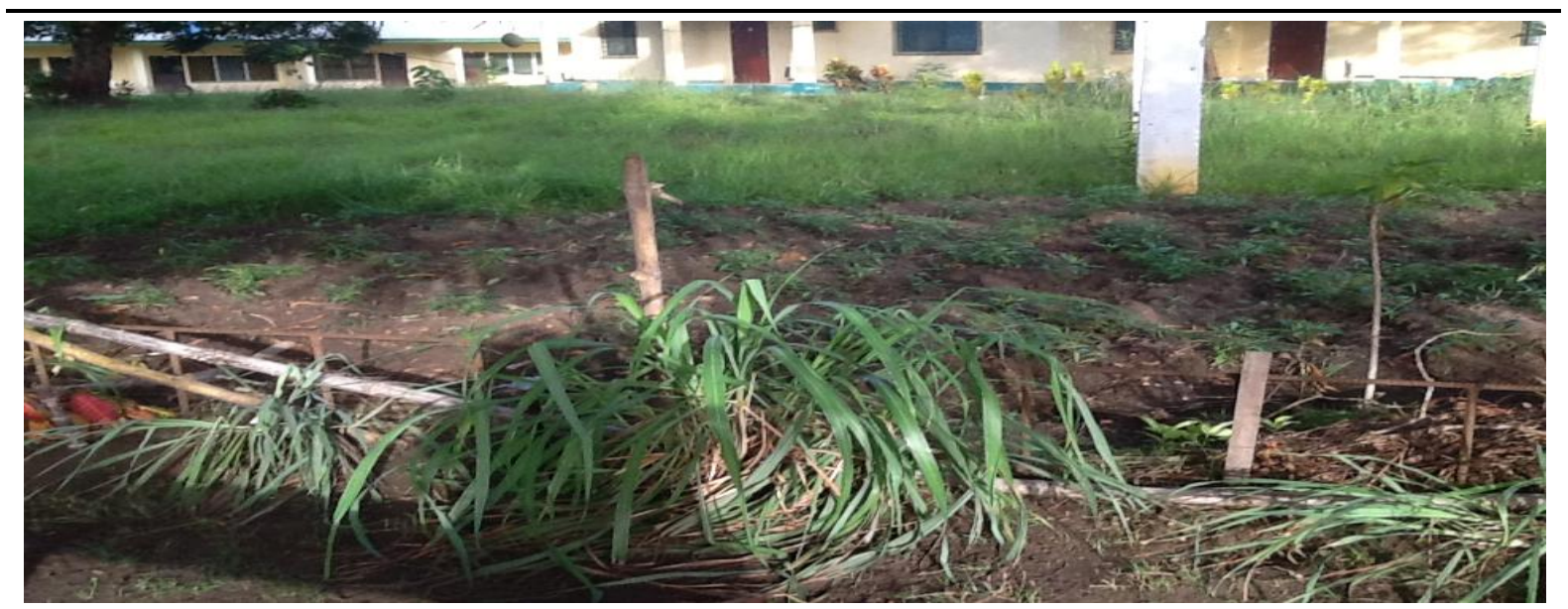

Figure 7. Chinese Building at Tubman University showing the Citronella Plants

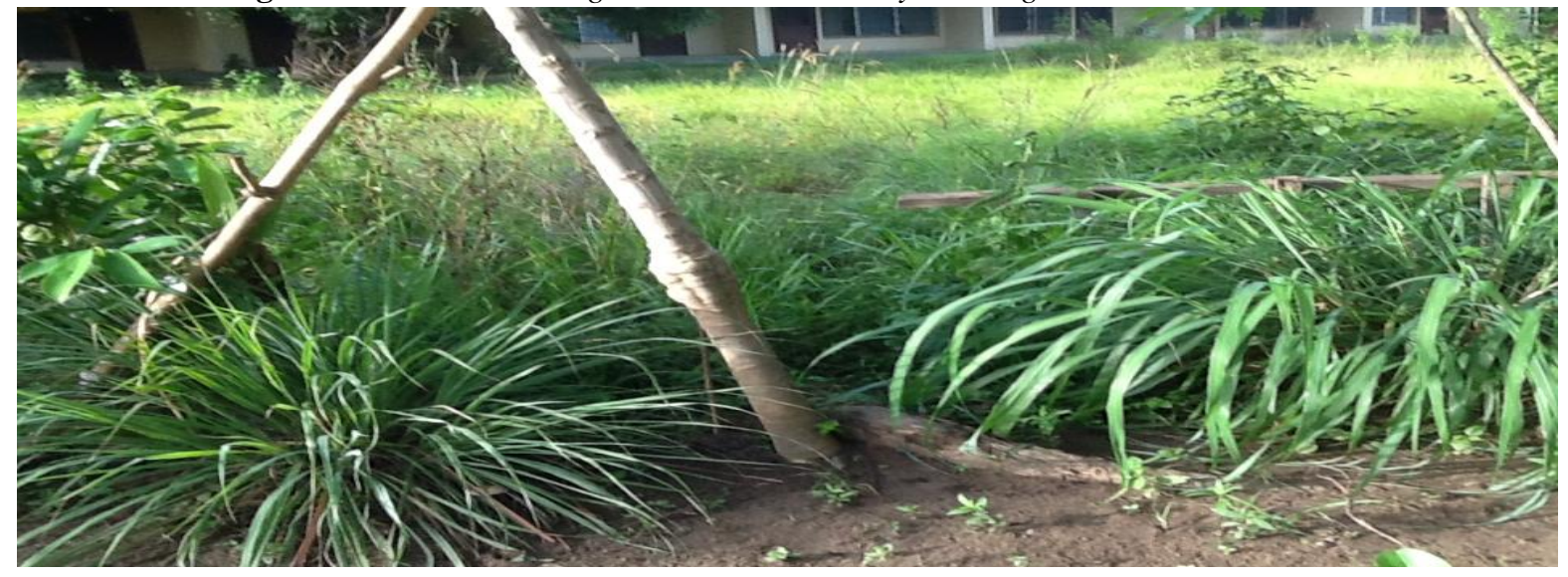

Figure 8. Front view of Chinese Building at Tubman University showing the Citronella Plants

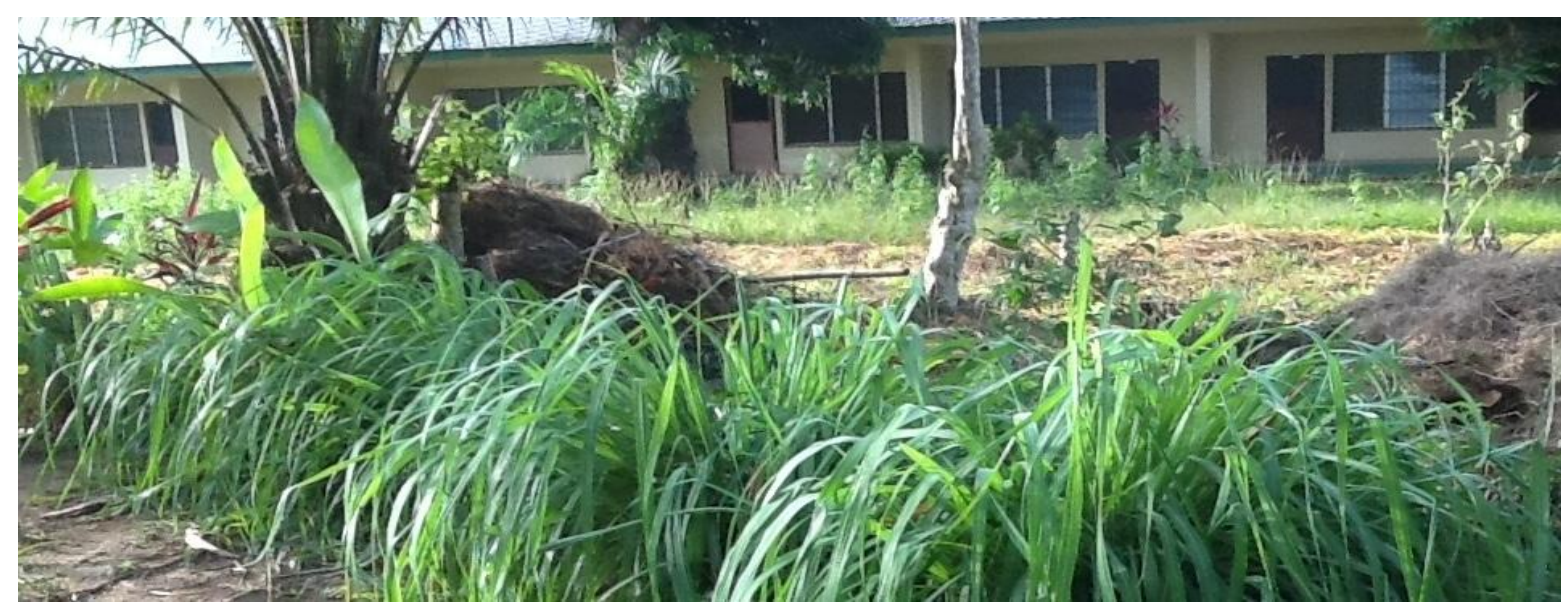

Figure 9. Part of the front view of Chinese Building at Tubman University showing the Citronella Plants

\section{RESUlT AND DISCUSSION}

The present study revealed the significant and important activity of Citronella Plants at Chinese building and the Tubman Hall of WVS Tubman University. This study aims to encourage the use of mosquito repellent "Citronella" which is based on natural resources.

\section{Observations of Mosquito Repellent Activity and Efficacies in the study area}

(i) Citronella plants help reducing human mosquito contact in the residents housing.

(ii) Citronella plants serve as a retardant of mosquito growthin the residents housing.

(iii) Citronella plants are a cost - effective intervention to potentially reduce incidence of new malaria cases in the residents housing. 
(iv) Citronella plants can serve as a basis for further study on using plants that have mosquito repellent abilities in their natural form to prevent and reduce incidences of mosquito borne diseases such as dengue fever, yellow fever etc.in the residents housing.

(v) Citronella plants prevent the incidence of malaria among the residents housing.

After further research study, it is the aim to the authors to encourage the planting of mosquito repellent plants such as "Citronella (which is based on natural resources)" around heavily populate work, living and play areas on the campus of the University as a natural alternative to decease the growth of disease carrying mosquitos.

\section{Conclusion}

The present study suggested that, the important activity of Citronella Plants in our Africa Countries where Malaria is very endemic should be taking serious in order to reduce and break out mosquitos in our surroundings. The natural mosquito repellents plants are seeing to be the best methods to repel mosquito as compare to chemical methods, non-chemical methods, mechanical methods and synthetic repellents methods. Though each of any of the methods has advantages and disadvantages; but the natural repellents plants are more economical to Africa context.

Furthermore, other ways to be guided from mosquito bite in other to avoid malaria as suggested by Richard J.P. et al are: wear long - sleeved shirts and long pants tucked into socks while you are working outdoors. While in doors, stay in air - conditioned or screened areas or use bed nets. Avoid mosquito breeding by clearing stagnant water from drains. Kick over buckets; put things under a roof of some kind. Mow the grass, tame the weedy areas, cut the high grass, cut the overgrown areas, duty rain gutters must be cleaned, swimming pool must be covered and get rid of things causing mosquitos now.

Further research work has been going on repellency tests and test for mortality which will be a continuation of this article as a paper II.

\section{ACKNOWLEDGMENTS}

The authors are grateful to the First President Professor Dr. Elizabeth, Davis Russell of Tubman University for allowing the Citronella Plants to be planted, we also thankful to the former Dean Theresa Feroline, Dean of College of Agriculture and Food Sciences for planting the Citronella Plants when the university started as fresh and mosquito was the order of the day. Your work Dean is being revisited for research, we appreciate you. The contribution of Late Dr.Abugarshall Kai is highly acknowledged.

\section{REFERENCES}

[1] The Bulb-o-licious Garden: http://www.lulu.com/spotlight/niphipps70

[2] Mosquito repellent plant: http://www.gardeningknowhow.com/plant-problems/pests/insects/ mosquito-repelling-plants.htm

[3] Lemongrass: http://www.gardeningknowhow.com/edible/herbs/lemongrass/learn-about-growinglemon-grass-plant.htm

[4] Parsley: http://www.gardeningknowhow.com/edible/herbs/parsley/tips-on-how-to-growparsley.htm

[5] Bansode, D.S. and Chavan, M.D. (2015)"Effect of Mint Leaves Extract on MDR Pathogens: A Comparative Study", European Journal of Pharmaceutical and Medical Research, Vol. 2(3), 409416.

[6] World Health Organization's World Malaria Report 2013 and the Global Malaria Action Plan

[7] Eliningaya, J.K, Franklin, M, Asanterabi, L., Aneth M. M, Jovin, K, Johnson, M., Michael, J.M., Charles, P.M., Filemoni, T., Emmanuel, F., Ester, E.L., Michael, A. M., Rajabu, M., Grace, C. and Emmanuel, A.T. (2008): "Ethnobotanical study of some of mosquito repellent plants in morth - eastern Tanzania" in the Malaria Journal of BioMed Central. Vol. 7 No 152, 1 - 9. DOI $1186 / 1475-2875-7-152$.

[8] Nathan, S.S., Kandaswamy, K., Kadarkarai, M (2005): Effect of neen limo - noids on the malaria vector Anopheles stephensiListon (Dip- tera: Cullicidae) Acta Trop 96: 47 - 55 
[9] Brooke, B.D., Humb, R.H, Koekemorer, L.L., Dossou - Yovo, J., Coetzee, M. (2000): "Evaluation of a polymerized chain reaction assay for detection of pyrethroid insecticide resistance in the malaria vector species of the An. gambiae complex" J. Am MosqControl Assoc 15: 565 - 568

[10] Lengeler, C, Smith, T. A, and Amstrong - Schellemberg, J. (1997): Focus on the effect of bednets on malaria control morbidity and mortality. Parasitol Today. 13: 123 - 124

[11] Beier, J.C',Killeeen, G.F., Girthure, J.I. (1999): "Short report: entomologic inoculation rates and Plasmodium falciparummalaria prevalence in Africa. Am J.Trop. Med Hyg. 61: 109 - 113.

[12] Casmiro, S., Coleman, M, Mohloai, P., Hemingway, J. Sharp, B. (2006): Insecticide resistance in Anophelesfunestus (Diptera: Culicidae) from Mozambique. J. Med Entomol 43: 267 - 275.

[13] Binka, F.N., Adongo, P. (1997): Acceptability and use of insecticide impregnated bed nets in Northern Ghana. Trop Med Int Health 2: 499 - 507

[14] Snow, R.W, McCabe E, Mbogo C. N. M., Molyneux, C. S., Same, E. S., Mung'ala, V.O., Nevill, C. G. (1999): The effect of delivery mechanism on the effect of bed net re - impregnation in Kilifi district, Kenya. Am J Trop Med Hyg 68: 137 - 141

[15] Patel, E. K., Guptal, A. and Oswal, R. J. (2012): "A review on: Mosquito repellant Methods" International Journal of Pharmaceutical Chemical and Biological Sciences. 2 (3): 310 - 317

[16] AakankshaWany, ShiveshJha,Vinod Kumar, N. and Dev Mani P.(2013): "Chemical analysis and therapeutic uses of citronella oil from cymbopogonwinterianus: a short review" International Journal of Advanced Research, Volume 1, Issue 6, 504-521

[17] Chistophers, S. R. (1947):“ Mosquito repellents. Being a report of the work of the mosquito repellent inquiry, Cambridge . J. Hyg. 45: 176 - 231.

[18] Dethier, V.D. (1947): Chemical insect attractants and repellents. The Blakiston Co., Philadelphia

[19] Tubman University Handbook, (2003): William V. S. Tubman University Handbook, Revision. Second Edition.Published by the Division of Institutional Advancement.

[20] Eliningaya J. Kweka, Franklin Mosha, AsanterabiLowassa, Aneth M. Mahande, JovinKitau, Johnson Matowo, Michael J. Mahande, Charles P. Massenga, FilemoniTenu, Emmanuel Feston, Easter E. Lyatuu, Michael A. Mboya, RajabuMndeme, Grace Chuwa and Emmwnuel A. Tenu (2008): Ethnobotanical study of some mosquito repellent plants in north - eastern Tanzania. Malaria Journal, Vol. 7, No 152, pages $1-9$.

[21] Richard, J.P., Anthony, E.K. and Andrew, S. (2002): Repelling Mosquitoes, N Engl J. Med 247: $2-3$.

[22] Seyoum A, Kileen G.F, Kabiru E.W, Knols B.G, and Hassanali A. (2003): Field efficacy of thermally expelled or live potted repellent plants against African malaria vectors in western Kenya. Trop. Med Int. Health 8: $1005-1011$.

[23] Secoy D. M and Smith A. E (1983): Use of plant in control of agricultural and domestic pests, Economic Botany, 37: 28 - 57.

[24] Yang R. Z and Tang C.S. (1988): Plants used for pest control in China - literaturereview, Economic Botany 42: 376 - 406.

[25] Kulkarni D. K. and Kumbhojkar M. S. (1996): Pest control in tribal areas - an ethno botanical approach, Ethnobotany 8: $56-59$

[26] Kulkarni D. K. and Kumbhojkar M. S. (2003): Ethno - agricultural study of Mahadeokolis in Maharashtra, India. Asian Agric - History, 7: 295 - 312 